\title{
In Vitro Effects of DuP 753, a Nonpeptide Angiotensin II Receptor Antagonist, on Human Platelets and Rat Vascular Smooth Muscle Cells
}

\author{
Michel Burnier, Gabriel Centeno, Eric Grouzmann, Philippe Walker, Bernard Waeber, and
} Hans R. Brunner

These experiments were designed to assess the ability of the new nonpeptide angiotensin II antagonist DuP 753 to inhibit the binding and, particularly, to antagonize the cellular response to angiotensin II in human platelets and primary cultures of rat aortic smooth muscle cells (SMC). The binding of ${ }^{125}$ I-angiotensin II was competitively inhibited by DuP 753 with a $50 \%$ binding inhibition $\left(\mathrm{IC}_{50}\right)$ of 5 to $6 \times 10^{-8} \mathrm{~mol} / \mathrm{L}$ in platelets and $1 \times 10^{-8} \mathrm{~mol} / \mathrm{L}$ in vascular SMC as compared to an $\mathrm{IC}_{50}$ of 5 to $7.5 \times$ $10^{-9} \mathrm{~mol} / \mathrm{L}$ with nonlabeled angiotensin II. In vascular SMC, DuP 753 completely abolished the ef- fects of angiotensin II on ${ }^{45} \mathrm{CaCl}_{2}$ efflux and ${ }^{45} \mathrm{CaCl}_{2}$ uptake. Moreover, in these latter cells, DuP 753 prevented the angiotensin II but not the vasopressin induced increase in cytosolic calcium. These results demonstrate that DuP 753 competes with angiotensin II binding to its receptor in both animal and human cells and selectively blocks the cellular response to angiotensin II. Am J Hypertens 1991;4:438443

KEY WORDS: DuP 753, angiotensin II, antagonist, platelets, smooth muscle cells.
B lockade of the renin-angiotensin system (RAS) has become in recent years a very effective approach for the treatment of hypertension and congestive heart failure. ${ }^{1-4}$ Today, the cascade of the RAS leading to the generation of angiotensin II (Ang II) and finally to the activation of the angiotensin II receptor can be interrupted at different sites either by inhibition of renin or angiotensin converting enzyme (ACE) or by direct competition with the binding of angiotensin II to its receptor. ${ }^{5-7}$

Historically, saralasin, a peptide analog of Ang II, was the first potent and specific receptor antagonist to be used to block the activity of the RAS. ${ }^{7}$ This drug allowed

From the Hypertension Division and Cardiovascular Research Group, University Hospital, Lausanne, Switzerland.

This work was supported by the Swiss National Foundation (No.

3.816-0.87) and the Cardiovascular Research Group Foundation.

These results were presented at the American Society of Hypertension annual meeting, May 18 to 21, 1990.

Address correspondence and reprint requests to Michel Burnier, MD, Division d'Hypertension CHUV, 1011 Lausanne, Switzerland. the crucial role of the RAS in the development and maintenance of hypertension in animal models ${ }^{8,9}$ and in human forms of hypertension to be demonstrated. ${ }^{10-12}$ The clinical use of this receptor antagonist, however, has been limited by its lack of oral bioavailability, its short duration of action, and by its inherent agonistic activity. ${ }^{10-12}$

Recently, several nonpeptide imidazole Ang II receptor antagonists have been produced. ${ }^{13,14}$ These compounds exhibit a high affinity for Ang II binding sites in rats. ${ }^{15}$ Moreover, they have been shown to decrease blood pressure in animal models of hypertension particularly in those associated with an increased activity of the RAS. ${ }^{15,16}$ DuP 753 is one of these new orally active Ang II receptor antagonists that effectively inhibit Ang II binding in vitro ${ }^{15,17}$ and exert functional Ang II antagonism in rabbit aorta. ${ }^{17}$ Oral administration of DuP 753 to renal hypertensive rats causes a dose-dependent decrease in blood pressure..$^{15-18}$ In healthy human volunteers, DuP 753 given orally abolishes the blood pressure response to exogenous Ang II. ${ }^{19}$ 
The present experiments were designed to study the ability of DuP 753 to inhibit the binding of Ang II in human platelets much as it does in rat vascular smooth muscle cells. In addition, the capacity of DuP 753 to antagonize the cellular calcium response to Ang II was evaluated in primary cultures of rat aortic smooth muscle cells.

\section{METHODS}

Binding Studies Angiotensin II binding was performed both on freshly isolated human platelets and primary cultures of rat aortic smooth muscle cells (SMC).

Angiotensin II Binding in Human Platelets Blood was drawn from the forearm veins of healthy volunteers and anticoagulated with sodium citrate. Platelets were then isolated as described by Le Quan Sang and Devynck. ${ }^{20}$ Platelet-rich plasma was washed twice at room temperature in Medium 199 containing $5 \mathrm{mmol} / \mathrm{L}$ EDTA, 0.2\% bovine serum albumin (BSA), $10 \mathrm{mmol} / \mathrm{L}$ HEPES and $1 \mathrm{mg} / \mathrm{mL}$ bacitracin ( $\mathrm{pH} 7.4,22^{\circ} \mathrm{C}$ ) (assay buffer). The platelets were counted automatically and the volume was adjusted to yield a concentration of $10^{6}$ cells $/ \mu \mathrm{L}$. Binding studies were performed as described by Mann et al. ${ }^{21}$ In brief, platelets were incubated for $3 \mathrm{~h}$ with $0.1 \mathrm{nmol} / \mathrm{L}{ }^{125} \mathrm{I}$-angiotensin II in a final volume of $100 \mu \mathrm{L}$ at $37^{\circ} \mathrm{C}$ in a shaking water bath. Incubations were stopped by dilution with assay buffer at $4^{\circ} \mathrm{C}$ and centrifugation at $10000 \mathrm{~g}$ for $5 \mathrm{~min}$. The supernatant was discarded and the platelets washed twice in medium 199 at $4^{\circ} \mathrm{C}$. Radioactivity was counted in a $\gamma$ counter. Nonspecific binding was assessed by adding unlabeled angiotensin II at $10^{-6} \mathrm{~mol} / \mathrm{L}$. Displacement of specifically bound ${ }^{125} \mathrm{I}$-angiotensin II was performed with increasing concentrations of Ang II, DuP 753 (Du Pont de Nemours, Wilmington, DE) and a nonrelevant peptide (morphine modulating peptide, MMP).

Angiotensin II Binding in Vascular Smooth Muscle Cells Primary cultures of rat aortic smooth muscle (6th to 7 th passage) cultured in Dulbecco's Modified Eagle Medium (DMEM) with 15\% fetal calf serum were used for these studies. Binding was performed 3 to 5 days after plating the cells on $3.5 \mathrm{~cm}$ dishes. At confluence, the cells were washed with the assay buffer (Medium 199 containing $0.2 \%$ BSA, $1 \mathrm{mg} / \mathrm{mL}$ bacitracin, and $10 \mathrm{mmol} / \mathrm{L} \mathrm{HEPES})$. They were then incubated for $1 \mathrm{~h}$ at $37^{\circ} \mathrm{C}$ with $0.01 \mathrm{nmol} / \mathrm{L}{ }^{125} \mathrm{I}$-angiotensin II. The experiments were terminated by aspirating the supernatant and washing the cells three times with the binding buffer. The cells were removed from the plates with a lysis buffer containing $0.1 \%$ sodium dodecyl sulphate (SDS), $2 \% \mathrm{Na}_{2} \mathrm{CO}_{3}$ and $0.1 \mathrm{~N} \mathrm{NaOH}$ and scraping with a "rubber policeman." Radioactivity was counted in a $\gamma$-counter. Displacement curves were performed with increasing concentrations of unlabeled angiotensin II, DuP 753, or saralasin.

Calcium Studies in Vascular Smooth Muscle Cells Primary cultures of rat aortic SMC (7th to 10th passage) grown to confluence in DMEM were used to study the ability of DuP 753 to interfere with the cellular response to Ang II.

${ }^{45} \mathrm{Ca}^{2+}$ Efflux The culture medium was removed by aspiration and the cells washed twice with a physiologic saline solution (PSS) and loaded with $5 \mu \mathrm{Ci}$ of ${ }^{45} \mathrm{CaCl}_{2}$ in $1 \mathrm{~mL}$ PSS at $37^{\circ} \mathrm{C}$ for $3 \mathrm{~h}$. After loading, the cultures were rapidly rinsed five times and another $1 \mathrm{~mL}$ of fresh PSS was added. The supernatant was removed and replaced with $1 \mathrm{~mL}$ PSS every $30 \mathrm{sec}$ for $6 \mathrm{~min}$. The direct effects of Ang II or DuP 753 were evaluated by adding the peptide or the drug at $3 \mathrm{~min}$. In some experiments, pretreatment with DuP 753 was done by adding various concentrations of the antagonist in the PSS buffer continuously from time 0 . The amount of ${ }^{45} \mathrm{Ca}^{2+}$ lost from the cells in 12 consecutive $30 \mathrm{sec}$ intervals and the amount remaining inside the cells at the end of the 6 min experiment was measured by liquid scintillation counting. The results are expressed as the percentage of the total ${ }^{45} \mathrm{Ca}^{2+}$ activity released in the supernatant during a 30 sec time interval.

${ }^{45} \mathrm{Ca}^{2+}$ Uptake The culture medium was removed and the cells washed several times with fresh PSS. The cells were allowed to equilibrate for $3 \mathrm{~h}$ in this new buffer. They were then incubated for $5 \mathrm{~min}$ with $2 \mu \mathrm{Ci}{ }^{45} \mathrm{CaCl}_{2}$ in the presence or absence of any effector in $1 \mathrm{~mL}$ PSS. To terminate uptake, extracellular ${ }^{45} \mathrm{CaCl}_{2}$ was removed by washing the cells rapidly five times with cold PSS containing $2 \mathrm{mmol} / \mathrm{L}$ EDTA. The cells were lysed with the lysis buffer described above and the intracellular radioactivity determined by liquid scintillation counting. Pretreatment with DuP 753 was done by adding various concentrations of the antagonist $\left(10^{-7}\right.$ to $10^{-4} \mathrm{~mol} / \mathrm{L}$ ) during the equilibration period. In one set of experiments, the cells were rinsed three times before the uptake was started. Protein was determined in all studies by the method of Lowry et al. ${ }^{22}$

Determination of Cytosolic Calcium $[\mathrm{Ca}]_{i}$ Confluent monolayer cultures of rat aortic SMC were harvested by gently scraping the dish with a "rubber policeman." The cells were centrifuged for $5 \mathrm{~min}$ at $200 \mathrm{~g}$ and resuspended in DMEM. Fura-2 AM (Molecular Probes, Eugene, OR) was added at a final concentration of $2.5 \mu \mathrm{mol} / \mathrm{L}$ from a stock solution in dimethyl sulfoxide. The cells were then incubated for $30 \mathrm{~min}$ in the dark at room temperature. After loading, the cells were washed once with fresh culture medium and resuspended in PSS at a concentration of $2 \times 10^{6}$ cells $/ \mathrm{mL}$. The Fura- 2 fluorescence was measured on a spectrofluorometer (LS 5, Perkin Elmer, Oakbrook, IL). The cells were kept in 
suspension by gentle stirring at $37^{\circ} \mathrm{C}$. Stimulation of the cells was performed with various agents including angiotensin II, vasopressin, or DuP 753. Maximum fluorescence was obtained by addition of Triton $X$ and minimum fluorescence by chelation of $\mathrm{Ca}$ with an excess of EDTA. The calculations of $[\mathrm{Ca}]_{i}$ were performed according to Grynkiewicz et al without corrections for extracellular $\mathrm{Ca}{ }^{23}$

Cytosolic calcium was also determined in human platelets using the fura- 2 method described above. For comparison some measurements have been done with the Quin-2 method reported earlier. ${ }^{24}$

Statistical Analysis Data are presented as mean \pm SEM. Statistical analysis was performed with a one-way analysis of variance. A $P<.05$ was considered significant.

\section{RESULTS}

Interaction with Ang II Binding The displacement of ${ }^{125} \mathrm{I}-$ Ang II by cold angiotensin II or DuP 753 in human platelets is shown in the upper panel of Figure 1. Ang II competes with the binding of radiolabeled Ang II with a $50 \%$ binding inhibition $\left(\mathrm{IC}_{50}\right)$ at $7.5 \times 10^{-9} \mathrm{~mol} / \mathrm{L}$. The
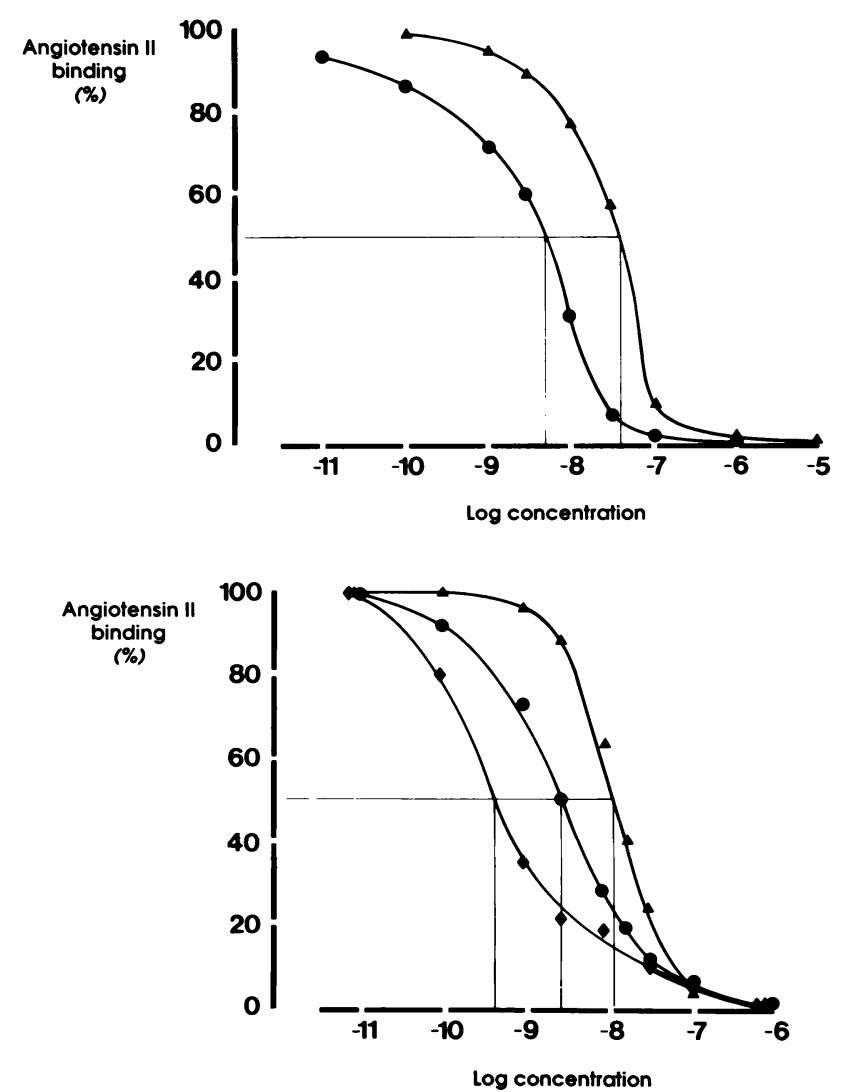

FIGURE 1. Effects of angiotensin II, DuP 753 or saralasin on ${ }^{125}$ I-angiotensin binding to human platelets (upper panel, $n=6$ in each curve) or rat aortic smooth muscle cells (lower panel, $n=3$ in each curve). angiotensin II, $\triangle$ DuP 753, $\diamond$ saralasin. binding of ${ }^{125} \mathrm{I}$-Ang II is displaced by DuP 753 with an $\mathrm{IC}_{50}$ of 5 to $6 \times 10^{-8} \mathrm{~mol} / \mathrm{L}$. In platelets, no displacement of the labeled Ang II has been obtained with MMP, a nonrelevant peptide. Similar results have been found in rat aortic SMC as shown on the lower panel of Figure 1 . In this cell type, the $\mathrm{IC}_{50}$ for cold Ang II is at $5 \times 10^{-9} \mathrm{~mol} / \mathrm{L}$. DuP 753 inhibits the Ang II binding with an $\mathrm{IC}_{50}$ of $1 \times 10^{-8} \mathrm{~mol} / \mathrm{L}$, whereas saralasin competes with Ang II with a higher affinity $\left(\mathrm{IC}_{50}\right.$ of 5 to $\left.7 \times 10^{-10} \mathrm{~mol} / \mathrm{L}\right)$.

Calcium Studies As shown in Figure 2, angiotensin II $\left(10^{-8} \mathrm{~mol} / \mathrm{L}\right)$ induces a significant increase in ${ }^{45} \mathrm{Ca}^{2+}$ efflux in rat aortic SMC when compared to the untreated cells. This calcium efflux is completely blocked by pretreatment with DuP $753\left(10^{-6} \mathrm{~mol} / \mathrm{L}\right)$. DuP 753 has no effect, per se, on calcium efflux in these cells (data not shown).

A significant increase in ${ }^{45} \mathrm{Ca}^{2+}$ uptake is also observed in aortic SMC after exposure to Ang II, an effect which can be prevented by preincubation of the cultures with DuP 753 (Figure 3). Interestingly, when the cells are washed three times after incubation with DuP 753, higher doses of DuP $753\left(10^{-4} \mathrm{~mol} / \mathrm{L}\right.$ instead of $10^{-6} \mathrm{~mol} / \mathrm{L}$ ) are needed to obtain an inhibition of the Ang II effect. In these conditions, at comparable molarity $\left(10^{-6} \mathrm{~mol} / \mathrm{L}\right)$, saralasin appears again to have a higher receptor affinity than DuP 753.

In addition to the inhibition of the Ang II-induced increases in calcium fluxes, DuP 753 also dose-dependently antagonizes the increase in cytosolic free calcium produced by Ang II (Figure 4). Indeed, cytosolic calcium increases from $144.3 \pm 6.6 \mathrm{nmol} / \mathrm{L} \quad(\mathrm{n}=13)$ to $367.4 \pm 7.2 \mathrm{nmol} / \mathrm{L}(\mathrm{n}=8, P<.001)$ after stimulation with Ang II $\left(10^{-7} \mathrm{~mol} / \mathrm{L}\right)$. Pretreatment with DuP 753 $\left(10^{-4} \mathrm{~mol} / \mathrm{L}\right)$ blunts the calcium response to Ang II with $\mathrm{a}[\mathrm{Ca}]_{\mathrm{i}}$ at $169.9 \pm 16 \mathrm{nmol} / \mathrm{L}(P<.001 v$ Ang II $)$. With a lower dose of the antagonist (DuP 753,10-6 $\mathrm{mol} / \mathrm{L}$ ), the Ang II stimulation is only partially attenuated resulting in a $[\mathrm{Ca}]_{\mathrm{i}}$ at $240 \pm 6.5 \mathrm{nmol} / \mathrm{L}(P<.01)$. Again, that DuP 753 has no effect, per se, even at a high concentration $\left(10^{-4} \mathrm{~mol} / \mathrm{L}\right)$ suggests that the compound has no agonistic effect. In these cells, DuP 753 does not affect the increase in cytosolic calcium induced by $10^{-7} \mathrm{~mol} / \mathrm{L}$ vasopressin (389 $\pm 35 \mathrm{nmol} / \mathrm{L}, \mathrm{n}=4)$.

In human platelets, no significant change in cytosolic calcium was observed after stimulation with angiotensin II when [Ca $]_{i}$ was determined with the Fura-2 or the Quin-2 methods.

\section{DISCUSSION}

Since stimulation of the angiotensin II receptor represents the ultimate step in the physiologic activation of the RAS, inhibition of angiotensin II binding by a specific receptor antagonist appears to be a logical and effective approach to decreasing the activity of this potent 
FIGURE 2. Effects of DuP 753 on the changes in ${ }^{45} \mathrm{CaCl}_{2}$ efflux induced by angiotensin II in rat aortic smooth muscle cells.

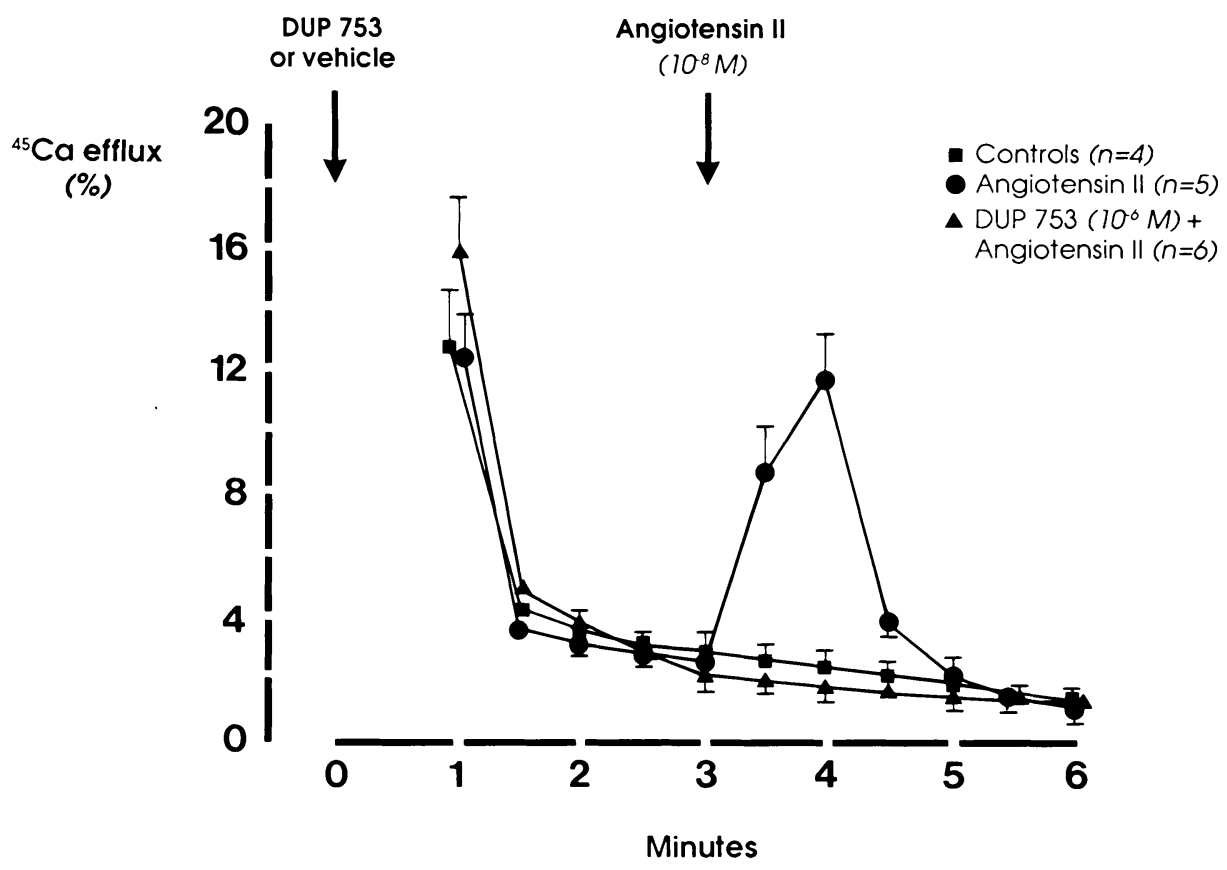

both in primary cultures of rat aortic SMC and in human platelets to assess the ability to block receptors located in animal as well as in human cell types. In our smooth muscle cells, DuP 753 inhibited the Ang II binding with an $\mathrm{IC}_{50}$ of $1 \times 10^{-8} \mathrm{~mol} / \mathrm{L}$, a value which is comparable to those obtained in the above-mentioned tissues. ${ }^{17}$ This new antagonist had less affinity for the angiotensin II receptor than saralasin, a finding which is also consistent with previous observations. ${ }^{17}$ The antagonist displaced $100 \%$ of the specific binding which suggests the presence of only one receptor type in these SMC.

Today, there is still little evidence available that DuP 753 acts as a specific antagonist to angiotensin II in experiments, angiotensin II binding was performed
The ability of DuP 753 to compete with angiotensin II at the receptor has been demonstrated in animal tissues such as rat adrenal cortical microsomes and rat aortic smooth muscle cells. ${ }^{17}$ In these two preparations, specific angiotensin II binding was inhibited by DuP 753 with an $\mathrm{IC}_{50}$ of about $2 \times 10^{-8} \mathrm{nmol} / \mathrm{L}$. In the present vasoconstrictor system. DuP 753 is a new nonpeptide peptidic analogs that have been used in the past to block the RAS, this compound has a long duration of action can be administered orally and seems to be devoid of any agonistic effect. ${ }^{15,17-19,26}$

753 a

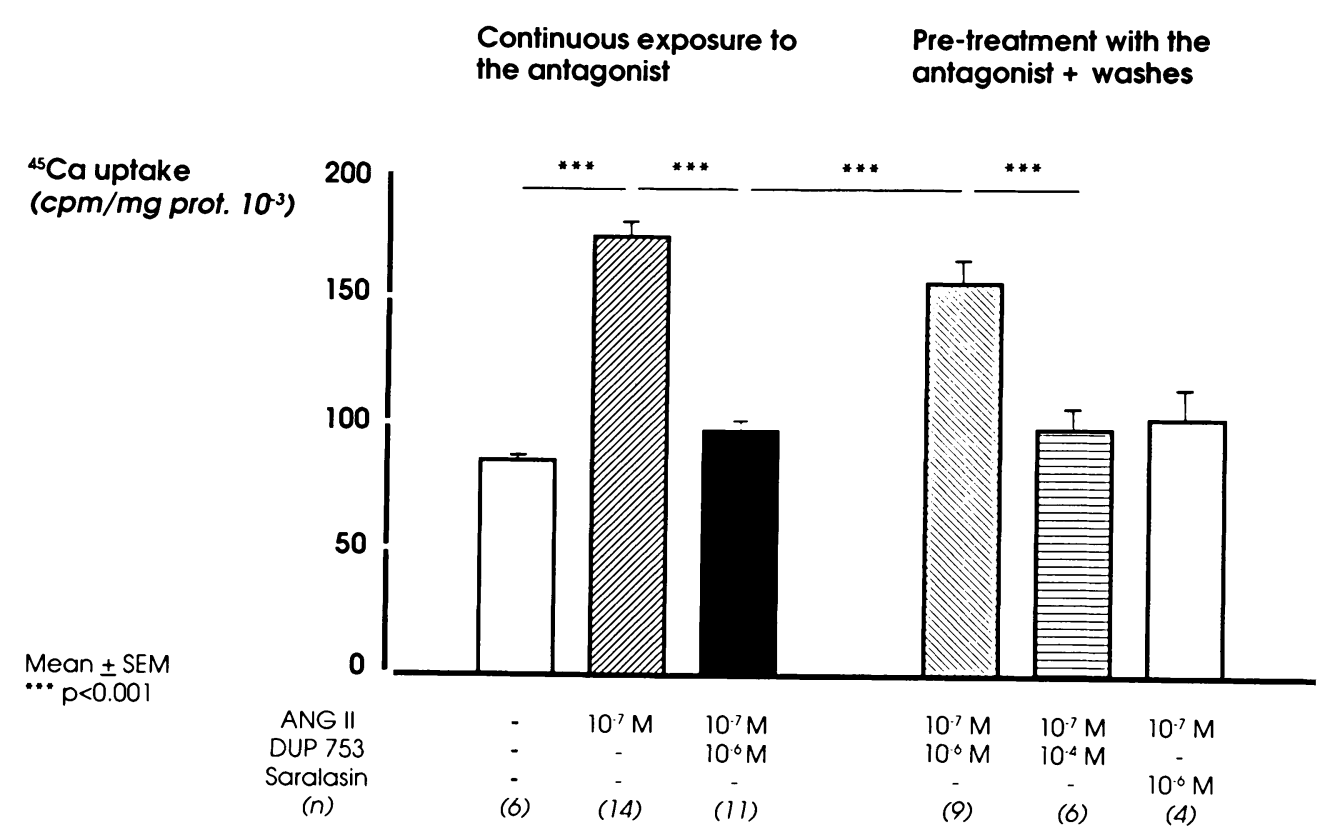

FIGURE 3. Effects of DuP 753 or saralasin on the changes in ${ }^{45} \mathrm{CaCl}_{2}$ uptake induced by angiotensin II in rat aortic smooth muscle cells. The cells were either continuously exposed to the antagonist or pretreated with the antagonist and washed before stimulation with angtiotensin II. 


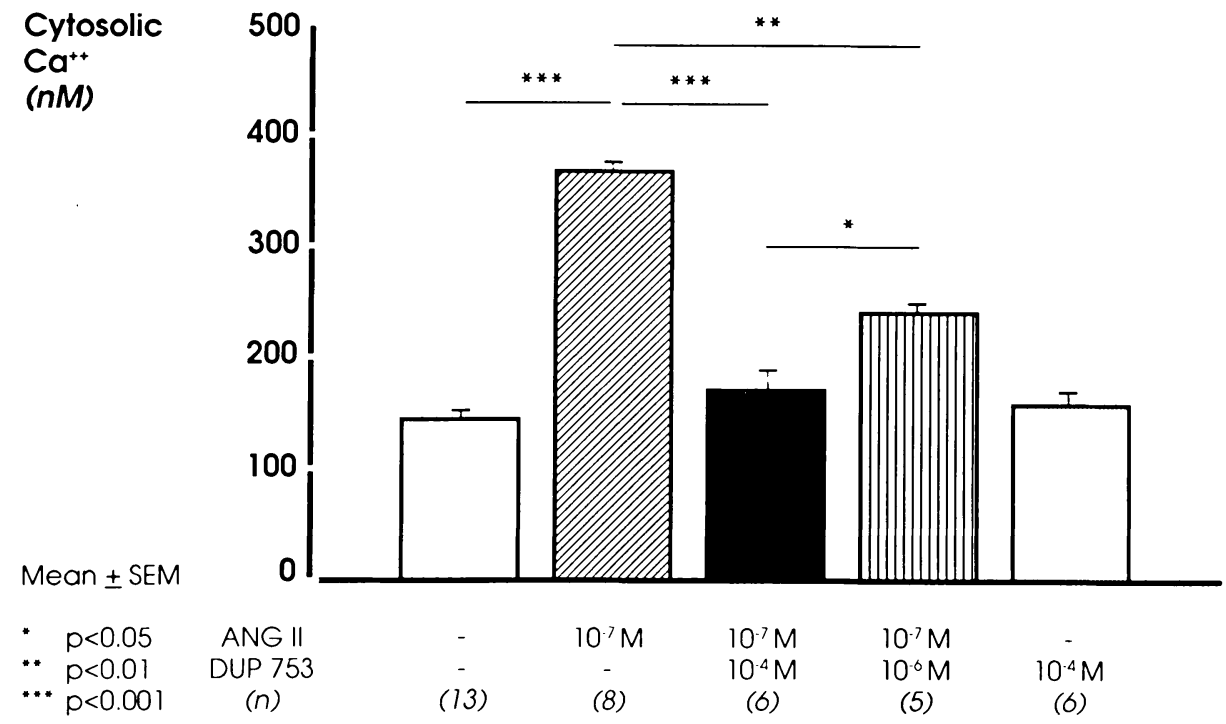

FIGURE 4. Effects of DuP 753 on the changes in cytosolic calcium induced by angiotensin II in rat aortic smooth muscle cells. humans besides the recent observation that DuP 753 administered orally to normotensive volunteers blunts the blood pressure response to exogenous angiotensin II. ${ }^{19}$ The results of the present study demonstrate that this antagonist is indeed capable of competing with the binding of angiotensin II in human cells such as platelets. The $\mathrm{IC}_{50}$ for DuP 753 in platelets $\left(5 \times 10^{-8} \mathrm{~mol} / \mathrm{L}\right)$ was again very similar to that reported in the literature for animal tissues. ${ }^{17}$

A physiologic action of angiotensin II on platelet function has still not been established although it has been suggested that angiotensin II might interfere with platelet aggregation..$^{25}$ The second messenger system coupled to the platelet angiotensin II receptor is also unknown. Using the Fura-2 method, we could not demonstrate any significant change in cytosolic free calcium after stimulation of the platelets with angiotensin II whereas a marked increase in cytosolic calcium was found after stimulation with vasopressin. ${ }^{24} \mathrm{~A}$ relatively low number of angiotensin binding sites per platelet might explain the difficulty to obtain a measurable signal. ${ }^{21}$ It is also possible that this receptor is not coupled to a calcium mediated pathway.

Angiotensin II binding in human platelets was performed originally in an attempt to monitor the degree of in vivo inhibition in volunteers receiving DuP 753 orally. For this purpose, we measured angiotensin II binding on platelets harvested before and after administration of the drug (Ref. 19 and unpublished results). Even at peak blockade of the blood pressure response to exogenous angiotensin II no decrease in angiotensin II binding was observed on the platelets of these volunteers. Our observation that DuP 753 is easily removed from the receptor at concentrations of $10^{-6} \mathrm{~mol} / \mathrm{L}$ when the cells are washed three times might explain why no binding inhibition was seen in platelets collected after administration of DuP 753. Most likely, the compound was displaced from the receptor during preparation of the platelets or during the repeated washes necessary to perform the angiotensin II binding.

The results of the calcium studies indicate that DuP 753 not only competes with the binding but also antagonizes effectively and specifically the cellular response to angiotensin II. Inhibition of angiotensin II-induced ${ }^{45} \mathrm{Ca}$ efflux by DuP 753 has been shown previously in SMC and is confirmed by the present experiments. ${ }^{17}$ In our hands, DuP 753 also blocked the cellular calcium uptake resulting from the angiotensin II stimulation. It is very unlikely that these effects of DuP 753 on calcium fluxes are due to a direct inhibitory effect of this compound on calcium channels. Indeed, previous studies have demonstrated that DuP 753 has absolutely no affinity for calcium channels. ${ }^{17}$

The measurement of free cytosolic calcium in vascular SMC is the definite way to look for an agonistic effect of the drug since cytosolic calcium is directly related to the activation of the receptor. In our aortic SMC, DuP 753 had no effect per se on cytosolic calcium suggesting no activation of the receptor by the drug itself. Moreover, our results confirm the specificity of the compound as DuP 753 blocked the angiotensin II-induced increase in cytosolic calcium but not that produced by vasopressin. This observation is in agreement with previous reports demonstrating no inhibitory activity of DuP 753 on several other receptors such as $\alpha_{1}$, vasopressin, serotonin, histamine, acetylcholine, and bradykinin. ${ }^{17,18,26}$

Finally, one has to recall that DuP 753 is metabolized and that active metabolites with different receptor affinities might be generated. A metabolism of DuP 753 has indeed been demonstrated in vivo in the rat and in vitro using human and rat liver microsomes ${ }^{27}$ All results obtained in vitro should therefore be interpreted cautiously particularly when trying to extrapolate from in vitro to in vivo antagonistic actions of the compound. 
Taken together, the results of the present experiments confirm that DuP 753 is an effective antagonist of angiotensin II which inhibits Ang II binding to its receptor in both animal and human cells and selectively blocks the cellular response to angiotensin II.

\section{REFERENCES}

1. Gavras H, Brunner HR, Turini GA, et al: Antihypertensive effect of oral angiotensin converting enzyme inhibitor SQ 14225 in man. N Engl J Med 1978;298:991-995.

2. Brunner HR, Nussberger J, Waeber B: Effects of angiotensin converting enzyme inhibition: a clinical point of view. J Cardiovasc Pharmacol 1985;7(suppl 4):73-81.

3. Turini GA, Brunner HR, Gribic M, et al: Improvement of chronic congestive heart failure by oral captopril. Lancet 1979;i:1213-1215.

4. The Consensus Trial Study Group: Effects of enalapril on morality in severe congestive heart failure. $\mathrm{N} \mathrm{Engl} \mathrm{J}$ Med 1987;23:1429-1435.

5. Delabays A, Nussberger J, Porchet $M$, et al: Hemodynamic and humoral effects of a new renin inhibitor enalkiren in normal humans. Hypertension 1989;13:941947.

6. Nussberger J, Delabays A, De Gasparo M, et al: Hemodynamic and biochemical consequences of renin inhibition by infusion of CGP $38560 \mathrm{~A}$ in normal volunteers. Hypertension 1989;13:948-953.

7. Pals DT, Masucci FD, Sipos F, Denning GS, Jr.: A specific competitive antagonist of the vascular action of angiotensin II. Circ Res 1971;29:664-672.

8. Brunner HR, Kirshmann JD, Sealey JE, Laragh JH: Hypertension of renal origin: evidence for two different mechanisms. Science 1971;174:1344-1346.

9. Gavras H, Brunner HR, Vaughan ED, Jr., Laragh JH: Angiotensin-sodium interaction in blood pressure maintenance of renal hypertensive and normotensive rats. Science 1973;180:1369-1372.

10. Brunner HR, Gavras H, Laragh JH, Keenan R: Angiotensin II blockade in man by $\operatorname{sar}^{1}$-ala ${ }^{8}$-angiotensin II for understanding and treatment of high blood pressure. Lancet 1973;ii:1045-1048.

11. Brunner HR, Gavras H, Laragh JH, Keenan R: Hypertension in man, exposure of the renin and sodium components using angiotensin II blockade. Circ Res 1974;34(suppl 1):35-43.

12. Streeten DHP, Anderson GH, Freiberg JM, Dalakos TG: Use of an angiotensin II antagonist (saralasin) in the recognition of angiotensinogenic hypertension. N Engl J Med 1975;292:657-662.

13. Furukawa $Y$, Kishimoto $S$, Nishikawa K: Hypotensive imidazole derivatives. Issued by Takeda Chemical Industries, Ltd., Osaka, Japan. US Patent 1982;4:340-598.

14. Wong PC, Chiu AT, Price WA, et al: Nonpeptide angiotensin II receptor antagonists. I. Pharmacological characterization of 2- $n$-butyl-4-chloro-1-(2-chlorobenzyl)imidazole-5-acetic acid, sodium salt (S-8307). J Pharmacol Exp Ther 1988;247:1-7.

15. Wong PC, Price WA, Chiu AT, et al: Nonpeptide angiotensin II receptor antagonists. Studies with EXP 9270 and DuP 753. Hypertension 1990;15:823-824.

16. Wong PC, Price WA, Chiu AT, et al: Nonpeptide angiotensin II receptor antagonists. IV. EXP 6155 and EXP 6803. Hypertension 1989;13:489-497.

17. Chiu AT, McCall DE, Price WA, et al: Nonpeptide angiotensin II receptor antagonists. VII. Cellular and biochemical pharmacology of DuP 753, an orally active antihypertensive agent. J Pharmacol Exp Ther 1990; 252:711-718.

18. Wong PC, Price WA, Chiu AT, et al: Nonpeptide angiotensin II receptor antagonists. IX. Antihypertensive activity in rats of DuP 753, an orally active antihypertensive agent. J Pharmacol Exp Ther 1990;252:726-732.

19. Christen $Y$, Waeber B, Nussberger J, et al: Oral administration of DuP 753, a specific angiotensin II antagonist, to normal volunteers. Circulation (in press).

20. Le Quan Sang KH, Devynck MA: Increased platelet cytosolic free calcium concentration in essential hypertension. J Hypertens 1986;4:567-574.

21. Mann JFE, Sis J, Ritz E: ${ }^{125} \mathrm{I}-$ Angiotensin II binding to human blood cells. J Hypertens 1985;3:131-137.

22. Lowry $\mathrm{OH}$, Rosebrough NJ, Farr AL, Randall RJ: Protein measurement with the Folin phenol reagent. J Biol Chem 1951;193:265-272.

23. Grynkiewicz G, Poenie P, Tsien RY: A new generation of $\mathrm{Ca}^{++}$indicators with greatly improved fluorescence properties. J Biol Chem 1985;260:3440-3450.

24. Mooser V, Burnier M, Nussberger J, et al: Effects of smoking and physical exercise on platelet free cytosolic calcium in healthy normotensive volunteers. J Hypertens 1989;7:211-216.

25. Poplowski A: The effect of angiotensin II on the platelet aggregation induced by adenosine-diphosphate, epinephrine and thrombin. Experientia 1970;26:86.

26. Wong PC, Price WA, Chiu AT, et al: Nonpeptide angiotensin II receptor antagonists. VIII. Characterization of functional antagonism displayed by DuP 753, an orally active antihypertensive agent. J Pharmacol Exp Ther 1990;252:719-725.

27. Du Pont Pharmaceuticals Internal Report: DuP 753, Clinical Investigators Brochure. April 1989. Wilmington, Delaware. 